\title{
Analiza wpływu przygotowania powierzchni zimną plazmą na lutowność stopów aluminium i magnezu
}

\author{
The influence of cold plasma-surface modification \\ on the solderability of aluminum and magnesium alloys
}

\section{Streszczenie}

W niniejszym artykule dokonano oceny zastosowania technologii zimnej plazmy atmosferycznej, jako metody przygotowania powierzchni metali trudno spajalnych do procesu lutowania. Omówiono materiały dodatkowe stosowane do lutowania twardego stopów magnezu i aluminium oraz wskazano na problemy występujące podczas ich lutowania. Przedstawiono wyniki badań lutowności poprzez próby zwilżalności i rozpływności, stopu aluminium PA11 przy użyciu spoiwa Al 112 (B-Al88Si12) i topnika Al 700 oraz stopu magnezu AZ31B przy użyciu spoiwa Mg 001 (B-MgAl9Zn3Mn1) i topnika FMAG opracowanego w Instytucie Spawalnictwa w Gliwicach. Przeprowadzono analizę porównawczą prób zwilżalności i rozpływności przed i po obróbce zimną plazmą. Wykazano znaczący wpływ obróbki zimną plazmą atmosferyczną na poprawę lutowności stopów aluminium PA1 1 i magnezu AZ31B.

Słowa kluczowe: zimna plazma; lutowanie magnezu; lutowanie aluminium; lutowność

\begin{abstract}
In this article the possibility of application of cold plasma technology for surface treatment of difficult-to-braze metals (PA11 aluminum alloys and AZ31B magnesium alloys) was evaluated. The filler metals used for brazing of magnesium and aluminum alloys, as well as the issues encountered during the process were discussed. The research were carried out: wettability and spreadability tests of PA11 aluminum alloy using Al 112 (B-Al88Si12) braze and Al 700 flux; and flame brazing of AZ31B magnesium alloy using Mg 001 (B-MgAI9Zn3Mn1) braze and FMGA flux developed at the Welding Institute in Gliwice. The wetting and spreadability were investigated with and without the use of cold plasma treatment and a comparative analysis was presented. Finally, the significant effect of the cold plasma plasma-surface modification on the brazebility of PA11 aluminum alloys and AZ31B magnesium alloys was demonstrated.
\end{abstract}

Keywords: cold plasma; magnesium brazing; aliminum brazing; brazebility

\section{Wstęp}

Od drugiej połowy $\mathrm{XX}$ wieku zainteresowanie stopami aluminium i magnezu systematycznie rośnie. Ze względu na swoje właściwości znajdują zastosowanie m.in. w przemyśle motoryzacyjnym, budowlanym, elektronicznym, lotniczym i kosmicznym $[5,7,9,11]$. Stopy te dzięki małej gęstości (dla magnezu ok. 1,7 kg/dm ; dla aluminium ok. 2,8 kg/dm ${ }^{3}$ ), dobrej wytrzymałości i odporności na korozję są bardzo korzystnymi materiałami konstrukcyjnymi. W przypadku magnezu oprócz bardzo małej gęstości niewątpliwy atut stanowi wysoka zdolność do tłumienia drgań $[3,4,7,8]$.

Zarówno stopy magnezu, jak i aluminium należą do grupy materiałów trudno spajalnych. Szczególne trudności przysparza ich lutowanie. Wpływ na to ma ich stosunkowo niska temperatura topnienia. W przypadku aluminium szczególnie niekorzystna jest wysoka temperatura topnienia tlenków $\mathrm{Al}_{2} \mathrm{O}_{3}$ $\left(2060{ }^{\circ} \mathrm{C}\right)$, duża przewodność cieplna, duży współczynnik rozszerzalności liniowej oraz fakt, że po nagrzaniu do temperatury lutowania twardego aluminium i jego stopy wykazują spadek właściwości wytrzymałościowych [12].

W stopach magnezowych ze względu na niskie wartości temperatury solidus mogą wystąpić odkształcenia podczas lutowania, złącza mogą wykazywać niską odporność na korozję atmosferyczną, a łatwa erozja metalu łączonego przez spoiwo znacząco wpływa na obniżenie właściwości mechanicznych połączeń [4].

Główną komplikacją przy lutowaniu stopów Mg i Al, decydującą o poprawnym wykonaniu złącza, jest obecność powierzchniowej warstwy tlenków, ograniczającej jej zwilżanie spoiwami lutowniczymi [7]. Z powodu natychmiastowego ponownego utleniania się materiałów, zarówno mechaniczne, jak i chemiczne oczyszczanie powierzchni nie daje wymaganych rezultatów. W niniejszych badaniach podjęto próbę

Dr inż. Tomasz Wojdat; dr hab. inż. Zbigniew Zimniak, prof. PWr; Izabela Łącka - Politechnika Wrocławska.

Autor korespondencyjny/Corresponding author: zbigniew.zimniak@pwr.edu.pl 
poprawy lutowności stopów Al i Mg poprzez zmniejszenie napięcia powierzchniowego, stosując obróbkę zimną plazmą atmosferyczną. Efekt ten jest możliwy do osiągnięcia w wyniku zmniejszenia ilości zanieczyszczeń organicznych, w tym tlenkowych - nawet 4-krotne zmniejszenie ilości tlenu na powierzchni [6].

Zimna plazma atmosferyczna, nazywana czwartym stanem skupienia materii ze względu na swoją inność od stanu ciekłego, gazowego czy stałego, w przygotowaniu powierzchni jest głównie znana z zastosowania jej do tworzyw sztucznych [1,2]. Wykorzystywana jest m.in. w technologii chemicznej w celu: wytrawiania i modyfikacji powierzchni, osadzania cienkich warstw, oczyszczania ścieków, czy też w inżynierii biomedycznej do sterylizacji narzędzi [1].

\section{Materiały użyte do badań}

W badaniach zastosowano materiały podstawowe, które w warunkach przemysłowych często przysparzają problemów podczas ich spajania. Wybrano po jednym stopie aluminium i magnezu, o oznaczeniach odpowiednio PA1 1 i AZ31B. Materiały te należą do grupy materiałów trudno spajalnych, a z uwagi na coraz częstsze wykorzystanie ich w przemyśle motoryzacyjnym, lotniczym i kosmicznym, często istnieje potrzeba wytwarzania połączeń, w tym lutowanych, które pod względem właściwości eksploatacyjnych muszą spełniać często bardzo wysokie wymagania. Skład chemiczny i podstawowe właściwości stopów wybranych

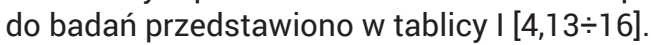

Do prób lutowania stopu aluminium PA11 wybrano okołoeutektyczny stop Al-Si o oznaczeniu Al 112 (B-Al88Si12) zawierający ok. $12 \%$ wag. Si oraz topnik oparty na bazie chlorków sodu i potasu o oznaczeniu Al 700. Temperatura aktywności topnika zawiera się w zakresie $500 \div 650{ }^{\circ} \mathrm{C}$. Natomiast do lutowania stopu magnezu AZ31B użyto lutu magnezowego o oznaczeniu Mg 001 (B-MgAl9Zn3Mn1) w połączeniu z topnikiem FMAG, opracowanym w Instytucie Spawalnictwa w Gliwicach, opartym na bazie chlorków potasu, litu i wapnia oraz fluorku sodu. Temperatura aktywności topnika FMAG mieści się w zakresie $400 \div 600{ }^{\circ} \mathrm{C}$ [4]. Skład chemiczny wraz z temperaturą topnienia wybranych lutów twardych przedstawiono w tablicy II.

\section{Próby rozpływności i zwilżalności}

Wykonanie połączeń lutowanych o dobrej jakości determinowane jest uzyskaniem dobrej zwilżalności powierzchni spoiwem lutowniczym. Aby lut mógł zwilżać i swobodnie rozpływać się po powierzchni spajanych materiałów należy zmniejszyć napięcie powierzchniowe. W przypadku stopów aluminium zawierających powyżej $2 \%$ wag. Mg i stopów magnezu, pomimo stosowania topników o dużej aktywności chemicznej, uzyskanie dobrej zwilżalności i rozpływności jest znacznie utrudnione z uwagi na dużą trwałość chemiczną warstwy tlenkowej, co może powodować problemy z uzyskaniem złączy o wysokiej jakości. W badaniach podjęto próbę polepszenia zwilżalności i rozpływności wybranych stopów Al i Mg poprzez zastosowanie technologii zimnej plazmy atmosferycznej bezpośrednio przed procesem lutowania.

Ponieważ obydwa parametry (zwilżalność i rozpływność) są ze sobą ściśle powiązane, to oceny skuteczności przygotowywania powierzchni do procesów lutowania metodą zimnej plazmy dokonano metodą rozpływności wybranych lutów na badanych podłożach. Z blach ze stopów Al i Mg o grubości 2,0 mm wycięto próbki o wymiarach 40 x 40 mm, których powierzchnię do badań przygotowano na dwa sposoby. odtłuszczenie rozpuszczalnikiem Nitro oraz poprzez obróbkę zimną plazmą wytworzoną z argonu, przy użyciu urządzenia o mocy $300 \mathrm{~W}$ i napięciu 18 kV (rys. 1). Czas oddziaływania strumienia zimnej plazmy na każdą próbkę wynosił $60 \mathrm{~s}$.

$\mathrm{Na}$ tak przygotowanych podłożach układano porcję lutu o masie 0,1 g wraz z topnikiem w takiej samej ilości i nagrzewano od góry płomieniem propanowo-powietrznym. Czas nagrzewania próbek od momentu stopienia się lutu wynosił $5 \mathrm{~s}$. Przygotowano po 5 próbek dla każdej z metod przygotowania powierzchni i dla każdego rodzaju lutu. W celu określenia rozpływności zmierzono pola powierzchni rozpłyniętych kropli lutu przy użyciu programu DP-Soft Olympus

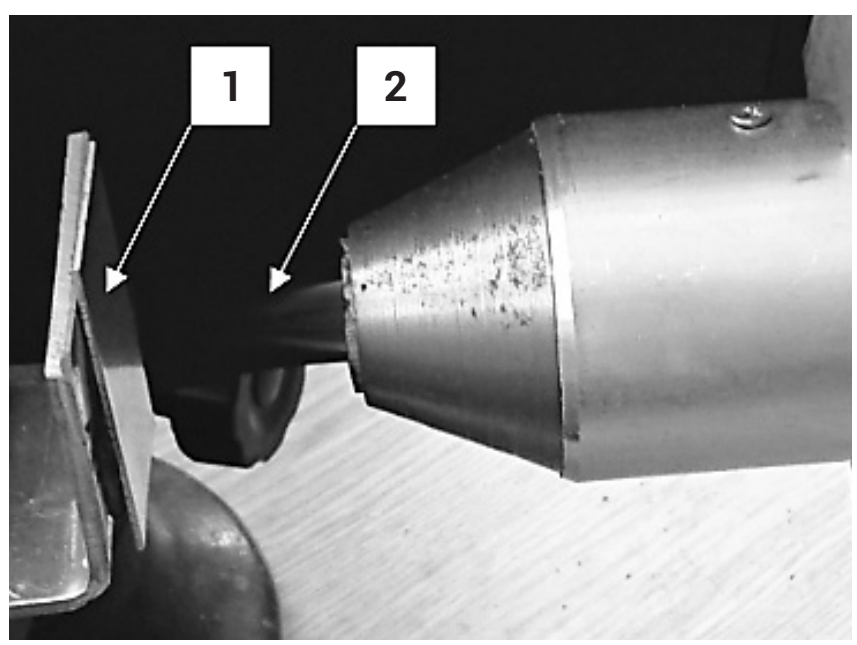

Rys. 1. Oczyszczanie powierzchni przy użyciu zimnej plazmy wytworzonej z argonu: 1 - próbka, 2 - strumień zimnej plazmy

Fig. 1. Surface cleaning using cold plasma generated from argon: 1 - sample, 2 - stream of cold plasma

Tablica I. Skład chemiczny i podstawowe właściwości stopu aluminium PA1 1 i magnezu AZ31B $[4,13 \div 16]$

Table I. Chemical composition and basic properties of aluminum alloy PA1 1 and magnesium AZ31B $[4,13 \div 16]$

\begin{tabular}{|c|c|c|c|c|c|c|c|c|}
\hline \multirow{2}{*}{ Oznaczenie } & \multicolumn{4}{|c|}{ Skład chemiczny [\% wag.] } & \multirow{2}{*}{$\begin{array}{l}\text { Temperatura } \\
\text { topnienia }\left[{ }^{\circ} \mathrm{C}\right]\end{array}$} & \multirow{2}{*}{$\begin{array}{l}\text { Gęstość } \\
{\left[\mathrm{kg} / \mathrm{dm}^{3}\right]}\end{array}$} & \multirow{2}{*}{$\begin{array}{c}\text { Wytrzymałość na } \\
\text { rozciąganie } R_{m}[\mathrm{MPa}]\end{array}$} & \multirow{2}{*}{$\begin{array}{c}\text { Wydłużenie } \\
\text { względne } A_{5}[\%]\end{array}$} \\
\hline & Al & Mg & $\mathrm{Zn}$ & inne & & & & \\
\hline PA11 & reszta & $2,6 \div 3,6$ & 0,2 & $0,5 \mathrm{Mn} ; 0,4 \mathrm{Si} ; 0,3 \mathrm{Cr}$ & $595 \div 645$ & 2,67 & $190 \div 200$ & $10 \div 14$ \\
\hline AZ31B & 3,0 & reszta & 1,0 & $0,2 \mathrm{Mn}$ & $605 \div 630$ & 1,77 & 193 & 14 \\
\hline
\end{tabular}

Tablica II. Skład chemiczny i temperatura topnienia lutów twardych Al 112 i Mg $001[4,13]$

Table II. Chemical composition and melting point of hard solders Al 112 i Mg $001[4,13]$

\begin{tabular}{|c|c|c|c|c|c|c|c|}
\hline \multirow{2}{*}{ Oznaczenie } & \multicolumn{5}{|c|}{ Skład chemiczny [\% wag.] } & \multirow{2}{*}{$\begin{array}{l}\text { Temperatura } \\
\text { topnienia }\left[{ }^{\circ} \mathrm{C}\right]\end{array}$} & \multirow{2}{*}{$\begin{array}{l}\text { Temperatura } \\
\text { lutowania }\left[{ }^{\circ} \mathrm{C}\right]\end{array}$} \\
\hline & Al & $\mathrm{Mg}$ & $\mathrm{Si}$ & $\mathrm{Zn}$ & inne & & \\
\hline Al 112 & reszta & - & 12,0 & - & - & $575 \div 585$ & $590 \div 610$ \\
\hline Mg 001 & $8,3 \div 9,7$ & reszta & - & $1,7 \div 2,3$ & $0,15 \div 0,5 \mathrm{Mn}$ & $443 \div 599$ & $582 \div 616$ \\
\hline
\end{tabular}


Tablica III. Wyniki prób rozpływności i zwilżalności na podłożach ze stopu aluminium PA1 1 i magnezu AZ31B

Table III. Results of spread and wettability tests on aluminum alloy substrates PA11 and magnesium AZ31B

\begin{tabular}{|c|c|c|}
\hline Materiał & Rozpływność $\mathrm{Pp}_{\text {sr }}\left[\mathbf{m m}^{2}\right]$ & Zwilżalność $\boldsymbol{\theta}\left[^{\circ}\right]$ \\
\hline PA11 & 184 & 12 \\
\hline PA11 + plazma & 285 & 5 \\
\hline AZ31B & 142 & 11 \\
\hline AZ31B + plazma & 405 & 4 \\
\hline
\end{tabular}

z funkcją planimetrowania powierzchni. Dla określenia zwilżalności, próbki przecięto w połowie rozpłyniętej kropli lutu, zainkludowano w żywicy epoksydowej i przygotowano zgłady metalograficzne. Następnie w sposób graficzny wyznaczono kąty zwilżania poszczególnych próbek. Wyniki pomiarów rozpływności i zwilżalności zestawiono w tablicy III. Są to wartości średnie z pięciu pomiarów.

Na rysunku 2 pokazano przykładowe pola rozpływności i kąty zwilżania lutów twardych na podłożach ze stopu aluminium PA1 1 i magnezu AZ31B.

Zastosowanie technologii zimnej plazmy, jako metody obróbki powierzchni stopu aluminium PA11 i magnezu AZ31B do procesu lutowania, spowodowało znacznie polepszenie rozpływności, o czym świadczą dużo większe pola powierzchni rozpłyniętych kropli spoiwa na obydwu podłożach oraz mniejsze wartości kąta zwilżania. Spowodowane jest to zmniejszeniem napięcia powierzchniowego oraz wyniku oczyszczenia (zmniejszeniem ilości zanieczyszczeń organicznych) powierzchni poddanych jej działaniu, przez co tworzący się w trakcie prób lutowania żużel topnikowy jest znacznie mniej nasycony tlenkami i mniej przyczepny do podłoża, umożliwiając swobodne zwilżanie i rozpływanie się lutu po materiale lutowanym. Przeprowadzone próby technologiczne potwierdzają dużą skuteczność technologii zimnej plazmy, jako metody przygotowania podłoży materiałów trudno spajalnych do procesu lutowania.

\section{Badania metalograficzne złączy lutowanych}

Skuteczność metody zimnej plazmy oceniono również na podstawie badań metalograficznych złączy lutowanych. Przygotowano zakładkowe złącza lutowane dla każdej z par metali z zastosowaniem oczyszczania powierzchni metodą zimnej plazmy wytworzonejz argonu ibez (powierzchnia tylko odtłuszczona). Długość zakładki wynosiła ok. $10 \mathrm{~mm}$, a szerokość szczeliny lutowniczej ustalono za pomocą stalowych drucików dystansowych na 0,2 mm. Podobnie jak w przypadku prób rozpływności złącza wykonano przez nagrzewanie płomieniowe przy użyciu palnika na propan-powietrze dozując ręcznie lut na krawędzi zakładki.

Podczas lutowania stopu aluminium PA11, niezależnie od sposobu przygotowania powierzchni łączonych materiałów, nie występowały problemy utrudniające wykonanie połączenia, a lut swobodnie wnikał do kapilarnej szczeliny. Badania metalograficzne złączy lutowanych wykazały jednak znaczące różnice w jakości złączy. W złączach, których elementy do lutowania przygotowano przez obróbkę zimną plazmą, występują śladowe ilości niezgodności lutowniczych w postaci niedużych wtrąceń żużla topnikowego (rys. 3a). Są to typowe niezgodności charakterystyczne dla procesu lutowania topnikowego, które nie stanowią zagrożenia dla prawidłowej funkcjonalności złącza. W przypadku złączy niepoddanych obróbce zimną plazmą występują nieciągłości lutownicze (miejsca niewypełnione lutem) spowodowane pozostałościami żużla topnikowego, niewypartego przez ciekły lut (rys. 3b). Spowodowane jest to dużym nasyceniem tlenkowym żużla, zwiększającym jego gęstość i przyczepność do podłoża, przez co jego wypieranie ze szczeliny przez spoiwo jest znacznie utrudnione.

Dużo bardziej utrudnione było wykonanie złączy ze stopu magnezu AZ31B. Problemy spowodowane były głównie przez małą różnicę pomiędzy temperaturą topnienia stopu AZ31B $\left(605 \div 630^{\circ} \mathrm{C}\right)$ i spoiwa Mg 001, którego górna granica likwidus wynosi $599^{\circ} \mathrm{C}$ (zalecana temperatura lutowania $582 \div 616^{\circ} \mathrm{C}$ ) [4]. Tak nieduża różnica temperatury topnienia spoiwa i materiału rodzimego jest szczególnie niekorzystna
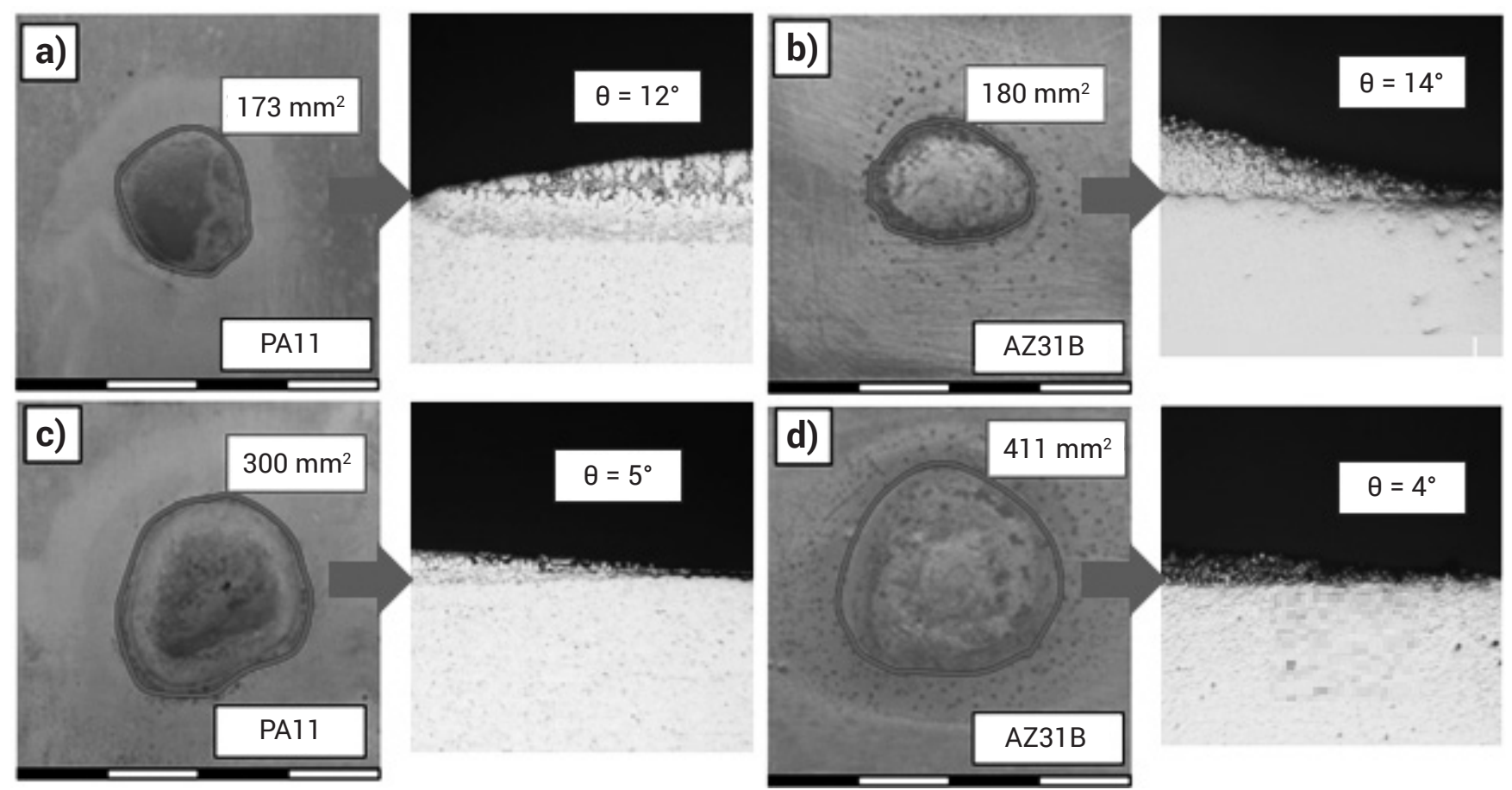

Rys. 2. Rozpływność i zwilżalność lutów twardych na podłożach ze stopu aluminium PA11 i magnezu: a, b) powierzchnia odtłuszczona, c, d) powierzchnia poddana działaniu zimnej plazmy

Fig. 2. Wettability and wetting of hard solders on aluminum alloy PA11 and magnesium substrates: a, b) degreased surface, c, d) surface treated with cold plasma 

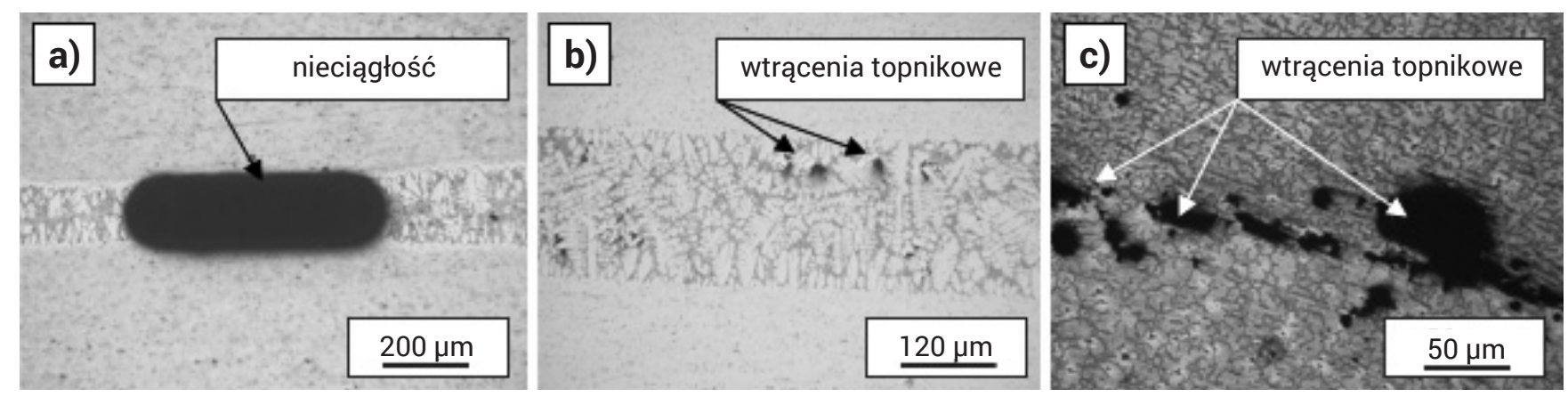

Rys. 3. Mikrostruktura złączy lutowanych: a) stop aluminium PA11 bez obróbki zimną plazmą, b) stop aluminium PA11 po obróbce zimną plazmą, c) stop magnezu AZ31B po obróbce zimną plazmą

Fig. 3. Microstructure of solder joints: a) PA11 aluminum alloy without cold plasma treatment, b) PA11 aluminum alloy after cold plasma treatment, c) AZ31B magnesium alloy after cold plasma treatment

w przypadku lutowania elementów o grubości poniżej 3,0 mm, a która w rozpatrywanym przypadku wynosiła $2,0 \mathrm{~mm}$. Powodowało to, że w konsekwencji wykonanie złącza bez odpowiedniego przygotowania powierzchni łączonych elementów było niemożliwe. Podczas lutowania tworzył się silnie nasycony tlenkami żużel topnikowy ograniczający kapilarne wnikanie spoiwa magnezowego o małej gęstości (mniejszej od gęstości żużla) do szczeliny lutowniczej. Próba wykonania złącza wymagała zatem wydłużenia czasu lutowania, co skutkowało przegrzaniem materiału rodzimego, powodując jego nadtapianie się od krawędzi uniemożliwiając tym samym utrzymanie kapilarnej szerokości szczeliny lutowniczej. Oczyszczenie powierzchni metodą zimnej plazmy umożliwiło wykonanie złącza lutowanego, ale należy podkreślić, że mimo wszystko lutowanie cienkich blach ze stopów Mg było utrudnione i wymagało dużej precyzji. Tworzący się żużel o mniejszym nasyceniu tlenkowym był bardziej rzadkopłynny i nie ograniczał swobodnego wnikania lutu do szczeliny lutowniczej, przez co uniknięto przegrzania i nadtopienia materiału rodzimego. Nie pozwoliło to jednak na całkowite wyeliminowanie niezgodności lutowniczych w postaci wtrąceń topnikowych (rys. 3c). Pomimo niedużego nasycenia żużla tlenkami i dużej rzadkopłynności, jego całkowite wyparcie przez lut ze szczeliny lutowniczej jest ograniczone małą gęstością spoiwa magnezowego.

\section{Wnioski}

Na podstawie analizy wyników otrzymanych z przeprowadzonych badań sformułować można następujące wnioski:

- technologia zimnej plazmy jest wysoce skuteczną metodą przygotowania powierzchni metali trudno spajalnych do procesów lutowania, o czym świadczą większe pola rozpływności i mniejsze wartości kątów zwilżania (różnica ok. 70\%);

- żużel topnikowy tworzący się na powierzchni metali poddanych działaniu zimnej plazmy jest mniej nasycony tlenkami i bardziej rzadkopłynny, przez co nie jest z nią silnie związany, ułatwiając tym samym swobodne rozpływanie się lutu i lepsze zwilżanie;

- oczyszczenie powierzchni stopów aluminium i magnezu metodą zimnej plazmy umożliwia uzyskanie połączeń o wysokiej jakości, charakteryzujących się brakiem lub śladową ilością niezgodności lutowniczych typowych dla procesu lutowania z użyciem topnika;

- rzadkopłynny żużel o małym nasyceniu tlenkami, będący wynikiem użycia zimnej plazmy, jest skutecznie wypierany ze szczeliny lutowniczej przez ciekły lut, nawet o małej gęstości (luty magnezowe i aluminiowe), zmniejszając ryzyko występowania niezgodności w lutowinie.

\section{Literatura}

[1] Stryczewska H. D.: Technologie zimnej plazmy. Wytwarzanie, modelowanie, zastosowania, Elektryka, Zeszyt 1, 2011, s. 41-61.

[2] Bernaciak M.: Technologia aktywacji, czyszczenia i powlekania powierzchni tworzyw sztucznych, AMB Technic.

[3] Dziado A., Mola R.: Magnez - kierunki kształtowania własności mechanicznych, Obróbka Plastyczna Metali vol. XXIV, nr 4/2013, s. 253-277.

[4] Winiowski A., Majewski D.: Lutowanie twarde stopów magnezu, Przegląd Spawalnictwa vol. 86, nr 12/2014, s. 41-48.

[5] Alou A.: Magnesium: Current and Potential Automotive Applications, JOM, February 2002.

[6] Sorrentino L., Carrino L.: 2024 aluminium alloy wettability and superficial cleaning improvement by air cold plasma treatment, Journal of Materials Processing Technology, 2009, pp. 1400-1409.

[7] Piątkowski J., Binczyk F.: Właściwości i zastosowanie odlewniczych stopów Mg-Al, Archiwum Odlewnictwa, nr 4/2002.

[8] Dobrzański L.A.: Stopy metali lekkich, IMliB, Gliwice 2007.
[9] Janik B.: Zastosowanie stopów magnezu w lotnictwie, Prace Instytutu Lotnictwa, Warszawa 2011, s. 102-108.

[10] Szałatkiewicz J.: Zastosowanie plazmy w technice - aktualne tendencje, Pomiary Automatyka Robotyka 2/2010, s. 17-20.

[11] Kuczmaszewski J., Zaleski K.: Obróbka skrawaniem stopów aluminium i magnezu, Lublin 2015.

[12] Pilarczyk J. (red.): Poradnik inżyniera. Spawalnictwo, Tom 2, WNT, Warszawa 2005.

[13] PN-EN ISO 17672:2016-12 Lutowanie twarde - spoiwa.

[14] PN-EN 1754:2015-10 Magnez i stopy magnezu - System oznaczenia anod, gąsek i odlewów - Symbole materiału i numery materiału.

[15] PN-EN 485-2:2016-10 Aluminium i stopy aluminium - Blachy, taśmy i płyty - Część 2: Własności mechaniczne.

[16] PN EN 573-3:2014-02 Aluminium i stopy aluminium - Skład chemiczny i rodzaje wyrobów przerobionych plastycznie - Część 3: Skład chemiczny i rodzaje wyrobów. 